\title{
Experimental Findings on Minor Actinide and Lanthanide Separations using lon Exchange
}

Fuel Cycle Research \& Development

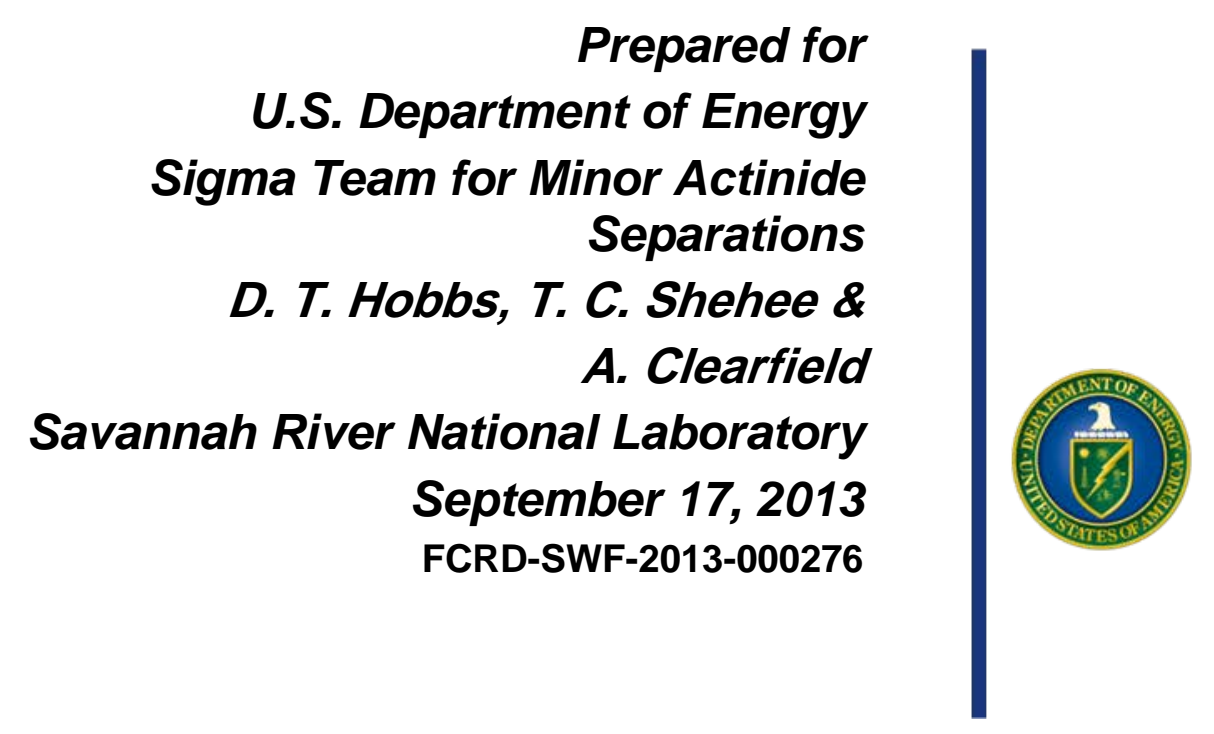


This information was prepared as an account of work sponsored by an agency of the U.S. Government. Neither the U.S. Government nor any agency thereof, nor any of their employees, makes any warranty,

expressed or implied, or assumes any legal liability or responsibility for the accuracy, completeness, or usefulness, of any information, apparatus, product, or process disclosed, or represents that its use would not infringe privately owned rights. References herein to any specific commercial product, process, or service by trade name, trade mark, manufacturer, or otherwise, does not necessarily constitute or imply its endorsement, recommendation, or favoring by the U.S. Government or any agency thereof. The views and opinions of authors expressed herein do not necessarily state or reflect those of the U.S. Government or any agency thereof. 


\section{Reviews and Approvals}

D. T. Hobbs, Co-author, Separations and Actinide Science Programs, SRNL Date

T. C. Shehee, Co-author, Separations and Actinide Science Programs, SRNL Date

A. Clearfield, Co-author, Texas A\&M University

Date

K. M. L. Taylor-Pashow, Technical Reviewer, SRNL

Date

Separations and Actinide Science Programs

T. B. Brown, Manager, Separations and Actinide Science Programs, SRNL Date

S. L. Marra, Manager, E\&CPT Research Programs, SRNL

Date

We put science to work. $^{\text {TM }}$ 


\section{SUMMARY}

This project seeks to determine if inorganic or hybrid inorganic ion-exchange materials can be exploited to provide effective americium and curium separations. Specifically, we seek to understand the fundamental structural and chemical factors responsible for the selectivity of the tested ion-exchange materials for actinide and lanthanide ions.

During FY13, experimental work focused in the following areas: (1) investigating methods to oxidize americium in dilute nitric acid with subsequent ion-exchange performance measurements of ion exchangers with the oxidized americium and (2) synthesis, characterization and testing of ion-exchange materials. Ion-exchange materials tested included alkali titanates, alkali titanosilicates, carbon nanotubes and group(IV) metal phosphonates.

Americium oxidation testing sought to determine the influence that other redox active components may have on the oxidation of $\mathrm{Am}(\mathrm{III})$. Experimental findings indicated that $\mathrm{Pu}(\mathrm{IV})$ is oxidized to $\mathrm{Pu}(\mathrm{VI})$ by peroxydisulfate, but there are no indications that the presence of plutonium affects the rate or extent of americium oxidation at the concentrations of peroxydisulfate being used. Tests also explored the influence of nitrite on the oxidation of $\mathrm{Am}(\mathrm{III})$. Given the formation of $\mathrm{Am}(\mathrm{V})$ and $\mathrm{Am}(\mathrm{VI})$ in the presence of nitrite, it appears that nitrite is not a strong deterrent to the oxidation of Am(III), but may be limiting $\mathrm{Am}(\mathrm{VI})$ by quickly reducing $\mathrm{Am}(\mathrm{VI})$ to $\mathrm{Am}(\mathrm{V})$. Interestingly, additional absorbance peaks were observed in the UV-Vis spectra at 524 and $544 \mathrm{~nm}$ in both nitric acid and perchloric acid solutions when the peroxydisulfate was added as a solution. These peaks have not been previously observed and do not correspond to the expected peak locations for oxidized americium in solution. Additional studies are in progress to identify these unknown peaks.

Three titanosilicate ion exchangers were synthesized using a microwave-accelerated reaction system $\left(\right.$ MARS $^{\circledR}$ ) and determined to have high affinities for lanthanide ions in dilute nitric acid. The K-TSP ion exchanger exhibited the highest affinity for lanthanides in dilute nitric acid solutions. The Ge-TSP ion exchanger shows promise as a material with high affinity, but additional tests are needed to confirm the preliminary results. On the other hand, carbon nanotubes and nitrogen-doped carbon nanotubes exhibited low, but measureable affinities for lanthanide ions in dilute nitric acid solutions ( $\mathrm{pH} 3$ and 6). The MWCNT exhibited much lower affinities than the K-TSP in dilute nitric acid solutions. However, the MWCNT are much more chemically stable in concentrated nitric acid solutions and, therefore, may be candidates for ion exchange in more concentrated nitric acid solutions.

This summary technical report serves as the deliverable documenting completion of the following FY13 research milestone:

M3FT-13SR0303064 - experimental findings on the study of inorganic and hybrid-type ion exchanger materials for effective minor actinide and lanthanide separations.

\section{We put science to work. ${ }^{\text {TM }}$}


ACRONYMS

$\begin{array}{ll}\text { CST } & \text { crystalline silicotitanate } \\ \mathrm{K}_{\mathrm{d}} & \text { distribution factor } \\ \text { MARS } & \text { microwave accelerated reaction system } \\ \text { MWCNT } & \text { multi-walled carbon nanotubes } \\ \text { SRNL } & \text { Savannah River National Laboratory } \\ \text { TAMU } & \text { Texas A\&M University } \\ \text { TSP } & \text { titanosilicate having the pharmacosiderite structure } \\ \text { UV-Vis } & \text { ultraviolet-visible }\end{array}$

We put science to work. ${ }^{\text {TM }}$ 


\section{SEPARATIONS}

\section{INTRODUCTION}

Our research project seeks to determine if minor actinide separations can be accomplished effectively using inorganic-based or hybrid ion-exchange materials. Over the last two decades a number of inorganic-based ion-exchange materials have been developed with high selectivity for radiochemical species in strongly alkaline environments. We postulate that selectivity for minor actinides can be tailored in inorganic materials for separations under acidic environments. Thus, we seek to understand the fundamental structural and chemical factors responsible for the selectivity of these ion-exchange materials for actinide and lanthanide ions.

\section{SIGNIFICANCE}

Inorganic ion-exchange materials generally exhibit much greater radiation and chemical stability than organic-based ion-exchange materials. Consequently, these materials may be used in much higher dose radiation environments compared to organic-based materials. This advantage may be significant in developing effective separations in feed streams in which Cs and Sr have not been previously separated. Ion-exchange separations can be easily deployed in continuous and semi-continuous modes at a variety of scales. Thus, there is considerable flexibility in deploying the separation technology. Depending on the framework of the ion-exchange material, the material may also serve as a final waste form matrix for the disposal of the separated radioisotopes.

The separation of Am and $\mathrm{Cm}$ is difficult using current liquid/liquid extraction technology. In aqueous solutions, Am and $\mathrm{Cm}$ have relatively similar chemistry; both are stable only in the trivalent oxidation state in simple aqueous solutions without added reagents to control oxidation state, and comparable charge to size ratios limit the discriminating driving forces commonly used in liquid extraction. Inorganic ion-exchange materials generally have much more rigid frameworks and coordination sites than those of the organic-based extractants employed in solvent extraction processes. This increased rigidity may amplify the ability to discriminate based on the slight size differences between the trivalent cations (i.e., Am and $\mathrm{Cm}$ ) compared to the more flexible coordination environments of the organic extractants.

\section{APPROACH}

Inorganic ion exchangers have found considerable use in the purification of wastewaters, treatment of alkaline nuclear waste solutions and in the purification of actinides in concentrated and dilute nitric acid solutions. Previous work has shown that titanates, titanosilicates and hybrid-type ion exchangers based on group IV metal phosphonates do exhibit high affinities for highly charged metal cations in dilute nitric acid solution. Furthermore, the affinity for a metal cation is reduced by lowering the effective charge of the species in solution. One such approach is the oxidation of Am(III) to form the americyl species, $\mathrm{AmO}_{2}{ }^{+}$or $\mathrm{AmO}_{2}{ }^{2+}$. During this year, we continued work exploring the oxidation of americium using peroxydisulfate in dilute nitric acid solution.

The inherent affinity of an ion exchanger for a particular metal ion can be influenced by a number of parameters including the oxidation state of the metal (i.e., effective charge density), acid concentration, and temperature. An attractive option to enhance separation of americium from curium and lanthanides is to oxidize the $A m(I I I)$ to $A m(V)$ or $A m(V I) .{ }^{1}$ The $A m(V)$ and $A m(V I)$ oxidation states will exist in

\section{We put science to work. ${ }^{\mathrm{TM}}$}


solution as the respective $\mathrm{AmO}_{2}{ }^{+}$and $\mathrm{AmO}_{2}{ }^{2+}$ species which have reduced charge density compared to $\mathrm{Am}^{3+}$ and $\mathrm{Ln}^{3+}$ ions. It would be expected that the ion exchangers would exhibit reduced affinity toward the $\mathrm{AmO}_{2}{ }^{+}$and $\mathrm{AmO}_{2}{ }^{2+}$ compared to that of $\mathrm{Am}^{3+}$ and the $\mathrm{Ln}^{3+}$ series of metal ions. Previous testing has shown that zirconium and tin(IV) hybrids of ideal composition $\mathrm{M}\left(\mathrm{O}_{3} \mathrm{PC}_{6} \mathrm{H}_{6} \mathrm{PO} 3\right)_{0 . .5}\left(\mathrm{HPO}_{4}\right)$, with $\mathrm{M}=\mathrm{Zr}$ and $\mathrm{Sn}$, and sodium titanates were effective in discriminating between ions of low charge $\leq 2+$ and those of $3+$ and $4+{ }^{1}$

\subsection{Am(III) Oxidation by Peroxydisulfate}

Studies continued to investigate the oxidation of americium as a prelude to ion-exchange separations. Oxidation of the $\mathrm{Am}(\mathrm{III})$ to $\mathrm{AmO}_{2}{ }^{+}$reduces the effective charge density of the americium compared to Am(III) and other +3 cations such as $\mathrm{Cm}$ (III) and the lanthanide(III) ions. Previous experiments have shown that the hybrid metal(IV) phosphonates and sodium titanate ion exchangers exhibit very high affinity for highly charged cations such as $\mathrm{M}^{3+}$ and lower affinity for mono- and di-cations. Thus, after oxidation of Am(III) to $\mathrm{AmO}_{2}{ }^{+}$, it would be expected that the ion exchangers would have a lower affinity for the $\mathrm{AmO}_{2}{ }^{+}$allowing separation between the americium and the more highly charged lanthanide ions, $\mathrm{Ln}(\mathrm{III})$, and $\mathrm{Cm}(\mathrm{III})$ ions.

For weakly acidic conditions ( $\mathrm{pH}$ 1-3), sodium peroxydisulfate, $\mathrm{N}_{2} \mathrm{~S}_{2} \mathrm{O}_{8}$, is an effective oxidizer for Am(III) in nitric and perchloric acid. Furthermore, as reported in the FY12 annual report, calcium hypochlorite, $\mathrm{Ca}(\mathrm{OCl})_{2}$, can serve as an effective stabilizing agent for $\mathrm{AmO}_{2}{ }^{+}{ }^{1}$. Thus, one would be able to treat a room temperature solution containing $\mathrm{AmO}_{2}{ }^{+}$along with lanthanides and $\mathrm{Cm}(\mathrm{III})$. During FY13 tests sought to determine the influence that other redox active components may have on the oxidation of Am(III). Experimental findings indicated that $\mathrm{Pu}(\mathrm{IV})$ is oxidized to $\mathrm{Pu}(\mathrm{VI})$ by peroxydisulfate, but there are no indications that the presence of plutonium affects the rate or extent of americium oxidation at the concentrations of peroxydisulfate being used.

Tests also explored the influence of nitrite on the oxidation of Am(III). The ratio of nitrite to Am(III) was varied from 1:2 to 10:1. Ratios for experiments and experimental concentrations can be found in Table 1. At a one-hundred fold excess of peroxydisulfate, little oxidation to the $A m(V)$ or Am(VI) occurred. Increasing the peroxydisulfate concentration to $0.3 \mathrm{M}$ produced $\mathrm{Am}(\mathrm{V})$ and a small amount of $\mathrm{Am}(\mathrm{VI})$ as shown in Figure 1. Similar results were found in dilute perchloric acid. Given the formation of Am(V) and $A m(V I)$ in the presence of nitrite, we conclude that nitrite is not a strong deterrent to the oxidation of Am(III), but may be limiting Am(VI) by quickly reducing Am(VI) to Am(V). Note, that additional peaks were observed at 524 and $544 \mathrm{~nm}$ as shown in the bottom spectrum of Figure 1 (nitric acid) and as well as in perchloric acid (Figure 2). These peaks have not been previously observed and do not correspond to the expected peak locations for oxidized americium in solution. These peaks do not appear when the peroxydisulfate is added as a solid versus being added as a solution. Thus, it appears that the additional peaks result from species produced by dissolution of the peroxydisulfate in water. Additional studies are in progress to identify these unknown peaks.

We also carried out a limited number of tests investigating the oxidation of americium under alkaline conditions with ozone followed by contact with sodium titanate ion exchangers. Under alkaline conditions, americium should be oxidized to Am(VI), whereas the lanthanides remain in the +3 oxidation state. Analysis of the filtrates after contact with the ion exchanges revealed that the bulk of the americium remained in solution and that most of the lanthanides had been removed.

\section{We put science to work. ${ }^{\text {TM }}$}




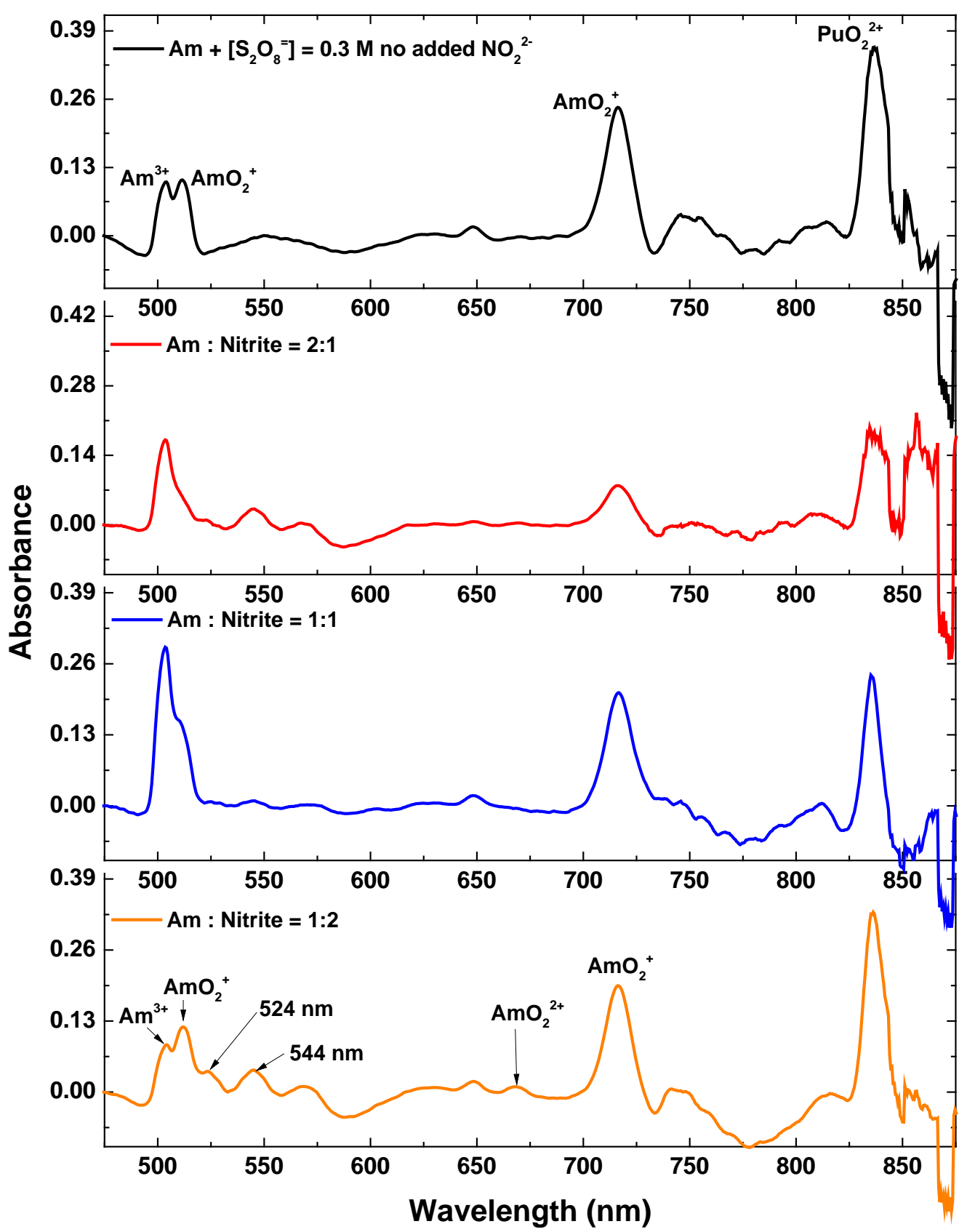

Figure 1. Oxidation of americium in nitric acid with varied nitrite concentrations 


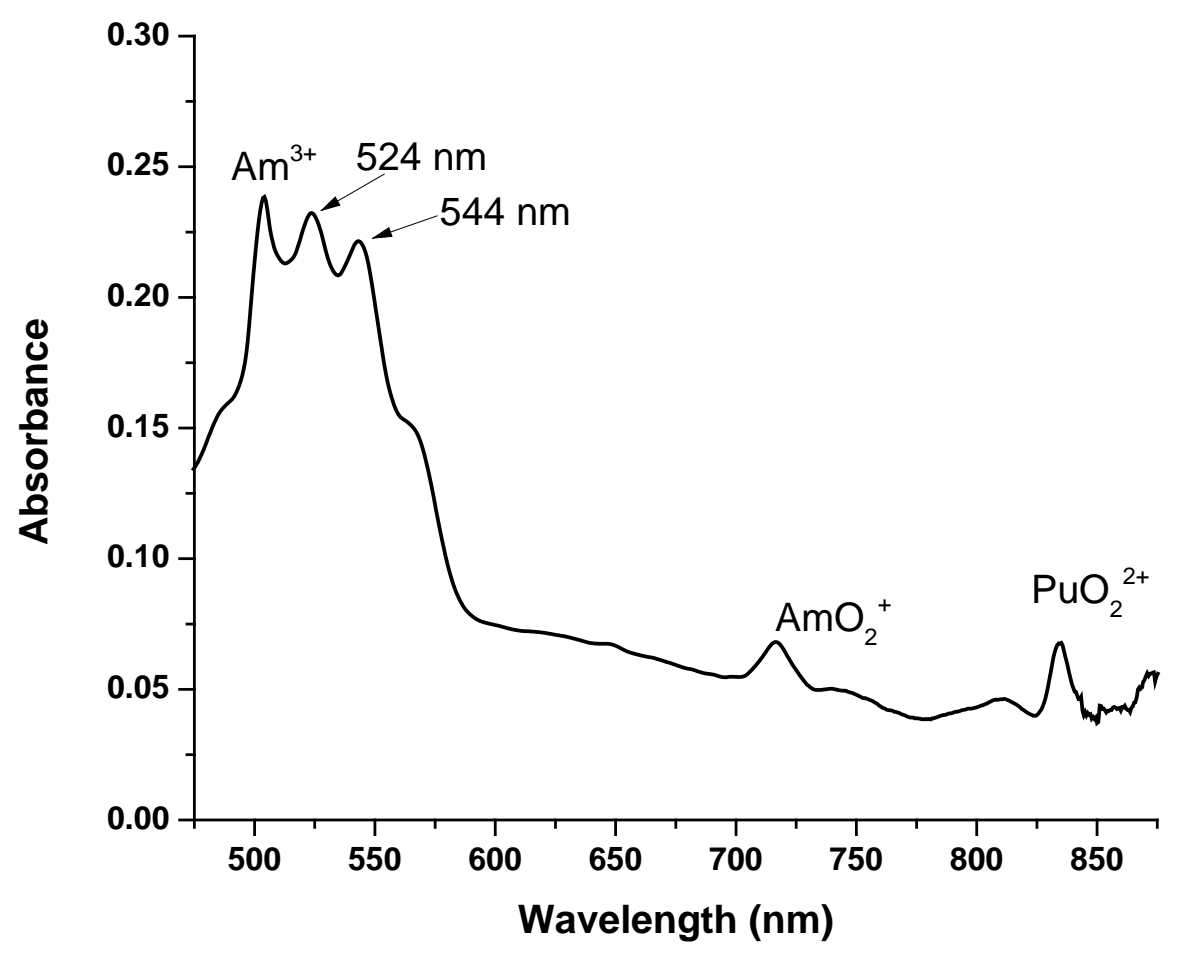

Figure 2. Oxidation of americium in perchloric acid by sodium peroxydisulfate 


\section{Table 1. Experimental conditions for evaluating the influence of nitrite and pH on americium oxidation}

\begin{tabular}{|c|c|c|c|c|c|c|c|c|c|}
\hline \multicolumn{10}{|c|}{ Mole ratio } \\
\hline $\mathrm{NaNO}_{2}$ & 1 & 2 & 0.5 & 1 & 2 & - & - & 1 & 10 \\
\hline Am & 1 & 1 & 1 & 1 & 1 & 1 & 1 & 1 & 1 \\
\hline \multicolumn{10}{|c|}{ Concentration of components } \\
\hline$\left[\mathrm{NaNO}_{2}\right](\mathrm{M})$ & $1.4 \times 10^{-6}$ & $2.8 \times 10^{-6}$ & $2.5 \times 10^{-6}$ & $3.4 \times 10^{-6}$ & $6.8 \times 10^{-6}$ & - & - & $3.9 \times 10^{-7}$ & $4.0 \times 10^{-8}$ \\
\hline [Am] (M) & $1.5 \times 10^{-6}$ & $1.5 \times 10^{-6}$ & $5.0 \times 10^{-6}$ & $5.0 \times 10^{-6}$ & $5.0 \times 10^{-6}$ & $5.0 \times 10^{-6}$ & $5.0 \times 10^{-6}$ & $5.0 \times 10^{-6}$ & $5.0 \times 10^{-6}$ \\
\hline $\begin{array}{c}{\left[\mathrm{Na}_{2} \mathrm{~S}_{2} \mathrm{O}_{8}\right]} \\
(\mathrm{M})\end{array}$ & $1.4 \times 10^{-4}$ & $1.4 \times 10^{-4}$ & 0.31 & 0.30 & 0.32 & 0.31 & 0.32 & 0.06 & 0.06 \\
\hline \multicolumn{10}{|c|}{ Volume } \\
\hline $\begin{array}{l}\text { Total system } \\
\text { volume }(\mathrm{mL})\end{array}$ & 2.06 & 2.09 & 2.95 & 3.00 & 2.97 & 2.90 & 2.95 & 2.60 & 2.50 \\
\hline \multicolumn{10}{|c|}{ pH } \\
\hline $\mathbf{p H}_{\text {final }}$ & N/A & N/A & N/A & N/A & N/A & 1.17 & 1.22 & N/A & N/A \\
\hline $\mathbf{p H}_{\text {target }}$ & 2 & 2 & 2 & 2 & 2 & 2 & 6 & 2 & 2 \\
\hline \multicolumn{10}{|c|}{ Media } \\
\hline & $\begin{array}{l}0.01 \mathrm{M} \\
\mathrm{HNO}_{3} \\
\end{array}$ & $\begin{array}{l}0.01 \mathrm{M} \\
\mathrm{HNO}_{3} \\
\end{array}$ & $\begin{array}{l}0.01 \mathrm{M} \\
\mathrm{HNO}_{3} \\
\end{array}$ & $\begin{array}{l}0.01 \mathrm{M} \\
\mathrm{HNO}_{3} \\
\end{array}$ & $\begin{array}{l}0.01 \mathrm{M} \\
\mathrm{HNO}_{3} \\
\end{array}$ & $\begin{array}{l}0.01 \mathrm{M} \\
\mathrm{HNO}_{3} \\
\end{array}$ & $\begin{array}{l}0.01 \mathrm{M} \\
\mathrm{HNO}_{3} \\
\end{array}$ & $\begin{array}{l}0.01 \mathrm{M} \\
\mathrm{HClO}_{4} \\
\end{array}$ & $\begin{array}{l}0.01 \mathrm{M} \\
\mathrm{HClO}_{4} \\
\end{array}$ \\
\hline
\end{tabular}

We put science to work."' 


\subsection{Ion-exchange Separations}

During FY13 research efforts explored the ion-exchange performance of several inorganic and hybrid ion exchangers. Ion-exchange materials studied included sodium titanates, sodium/potassium titanosilicates, multi-walled carbon nanotubes (MWCNT), and a series of $\mathrm{M}(\mathrm{IV})$ porous, pillared metal phosphonates of the general composition $\mathrm{M}\left(\mathrm{O}_{3} \mathrm{PC}_{6} \mathrm{H}_{4} \mathrm{PO}_{3}\right)_{1-x / 2}\left(\mathrm{O}_{3} \mathrm{POA}\right)_{\mathrm{x}}$ with $\mathrm{M}=\mathrm{Zr}^{4+}$ or $\mathrm{Sn}^{4+}$ and $\mathrm{A}=\mathrm{H}^{+}, \mathrm{Na}^{+}$or $\mathrm{K}^{+}$. Ion-exchange performance was measured over the $\mathrm{pH}$ range $2-6$. During FY13, TAMU researchers extended the family of hybrid materials by synthesizing the potassium forms of pillared metal phosphonates of $\mathrm{Zr}$ and $\mathrm{Sn}$. Compared to the corresponding proton and sodium forms, potassium metal phosphonates exhibited lower distribution values for $\operatorname{Ln}(\mathrm{III})$ ions in dilute nitric acid solutions.

Alkali-metal titanates and titanosilicates are typically prepared by a hydrothermal process in which the reagents are assembled, intimately mixed and heated for $3-8$ days at $170-200{ }^{\circ} \mathrm{C}^{2-4}$ During FY13, SRNL researchers investigated the synthesis of alkali metal titanosilicates using a microwave accelerated reaction system $\left(\mathrm{MARS}^{\circledR}\right)$. Powder X-ray diffraction patterns of the potassium titanosilicate (K-TSP) produced in the MARS ${ }^{\circledR}$ after 3 hours at $180{ }^{\circ} \mathrm{C}$ is nearly identical to that produced in a convention hydrothermal reactor after 8 days (see Figure 3). Thus, the reaction time in the MARS ${ }^{\circledR}$ is considerably shorter than that in the box oven. Interestingly, attempts to produce the sodium form of the TSP material in either reactor system resulted in the formation of a titanosilicate having a different framework structure, referred to as crystalline silicotitanate or Na-CST. The Na-TSP material can be produced by repeated contacts of the KTSP with a solution of $\mathrm{NaOH}$.

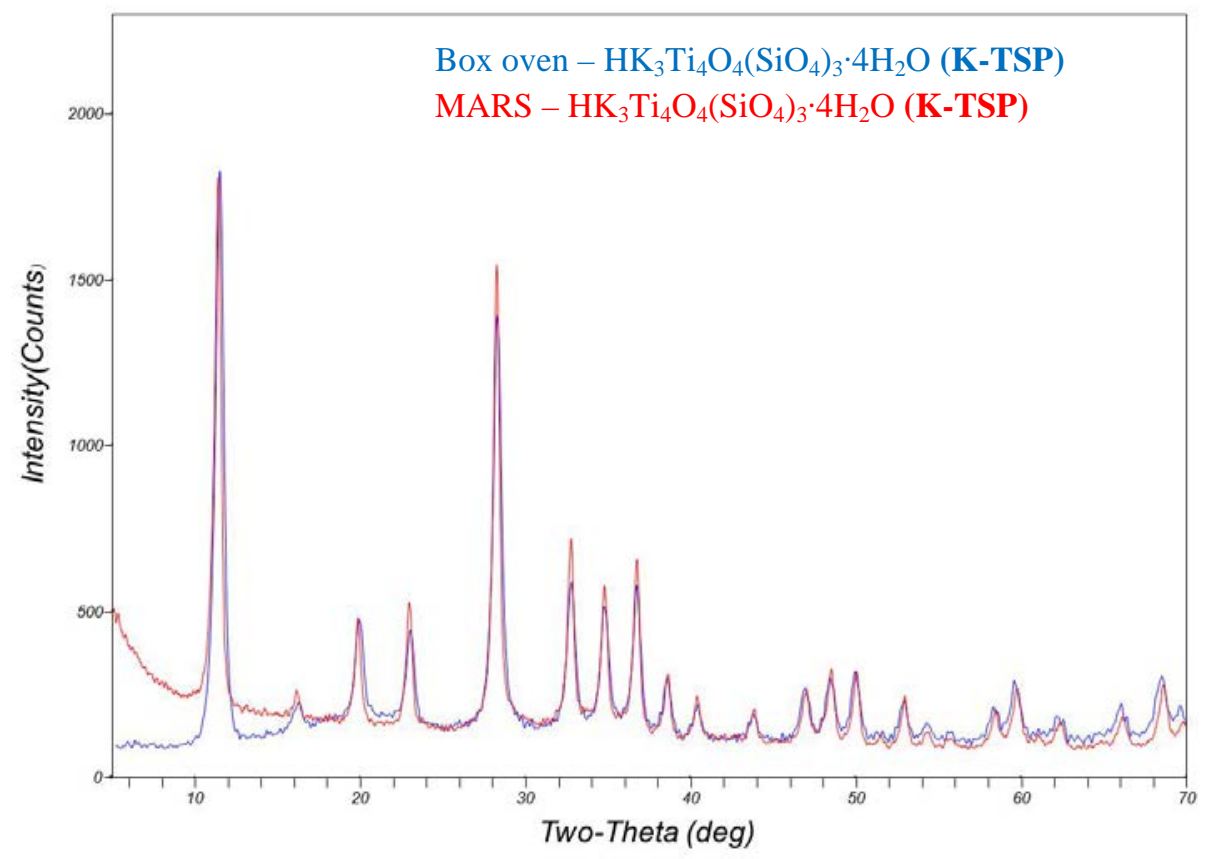

Figure 3. Powder X-ray Diffraction Spectra of K-TSP prepared by conventional hydrothermal (box oven) and in a microwave accelerated reaction system (MARS ${ }^{\circledR}$ ).

We put science to work."' 
Further tests indicate that germanium $(\mathrm{Ge})$ can be incorporated into the framework of the TSP material. Both the K-TSP and the Ge-substituted K-TSP exhibit high affinity for the Ln(III) and Am(III) ions in weakly acidic nitric acid solutions. Based on literature reports, Ge substitutes for both $\mathrm{Ti}$ and $\mathrm{Si}$ in the K-TSP., ${ }^{5,6}$ However, the location of the Ge in the K-TSP framework prepared in the MARS ${ }^{\circledR}$ has not been determined.

There are an increasing number of papers in the literature reporting the sorption of metal ions by porous carbons. ${ }^{7-9}$ Modification of the high surface area materials results in the formation of oxygen-functional groups such as carboxylates, alcohols and ketones that will complex with metal ions in aqueous solutions. ${ }^{10}$ There are also reports of incorporating nitrogen- and sulfurcontaining moieties onto the carbon surfaces as well. Although the distribution factors for porous carbons are generally not as high as those reported for the titanate, titanosilicates and hybrid ion exchangers, these materials are attractive materials for separations given their stability over a wide $\mathrm{pH}$ range, including concentrated mineral acids such as nitric acid, and high surface areas, which promote fast rates for the adsorption of metal ions.

During FY13, we investigated four commercially available MWCNT materials for the uptake of Ln(III) ions from dilute nitric acid solutions ( $\mathrm{pH} 3-6)$. Distribution factors ranged from about 5 $-50 \mathrm{~mL} / \mathrm{g}$ (see Figures 4 and 5) suggesting that these materials may be good candidates for the immobilized phase in chromatographic separations. Attempts to increase the oxygen-containing functional groups (and increase $\mathrm{K}_{\mathrm{d}}$ values) by treating with concentrated nitric acid solution did not appear to increase the uptake of Ln(III) by MWCNT. However, more careful control of the nitric acid treatment process (e.g., conversion of proton form to sodium form) may be more successful in increasing $\mathrm{K}_{\mathrm{d}}$ values.

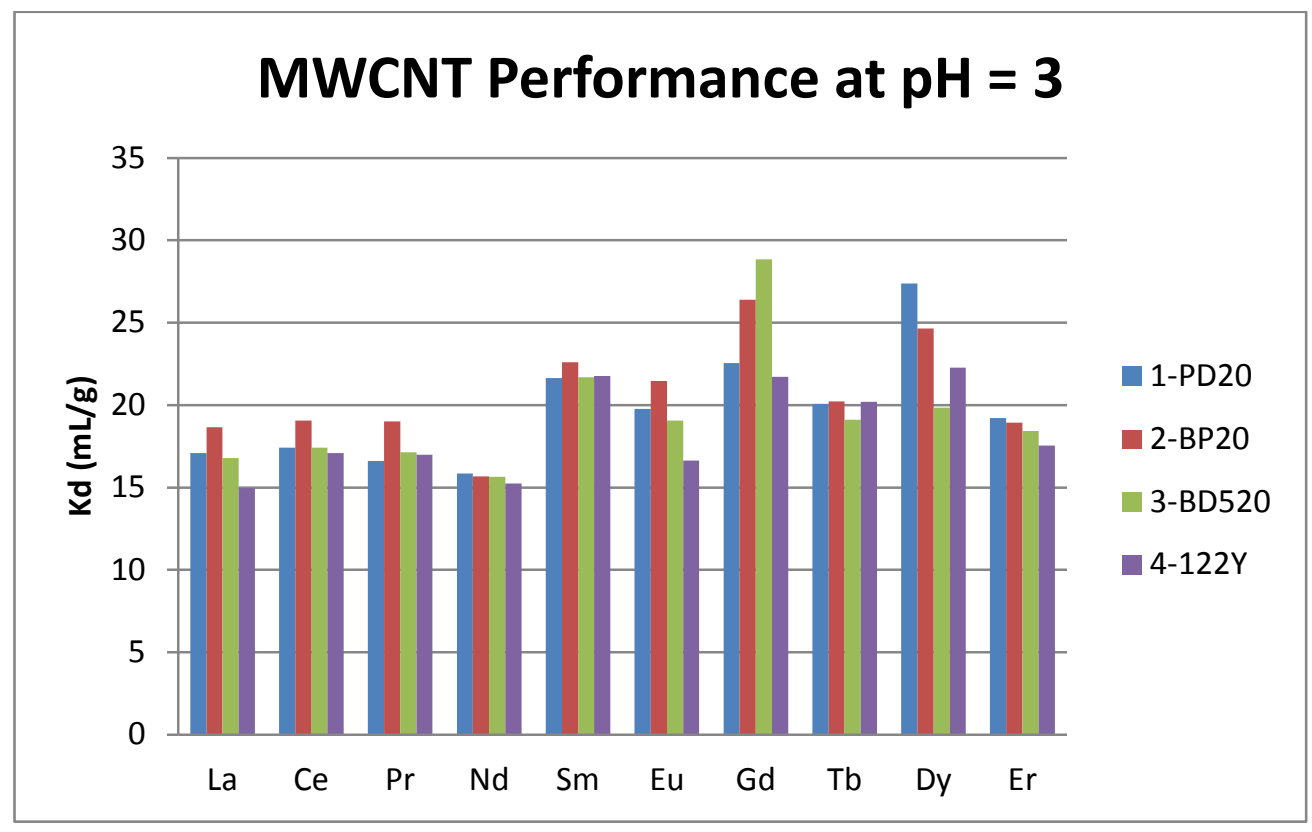

Figure 4. $\mathrm{K}_{\mathrm{d}}$ values for $\mathrm{Ln}^{3+}$ upon contact with MWCNT at pH 3.

\section{We put science to work. ${ }^{\text {'m }}$}




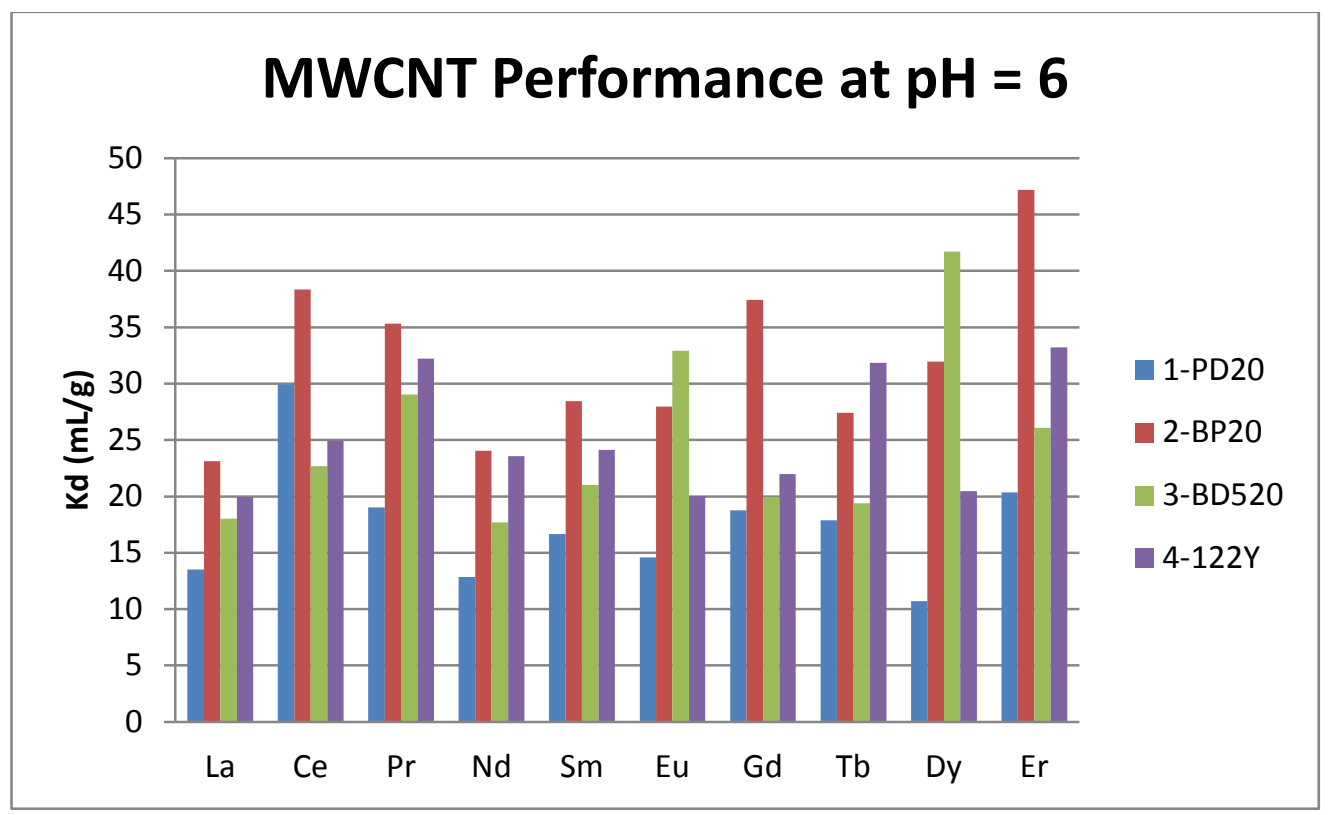

Figure 5. $\mathrm{K}_{\mathrm{d}}$ values for $\mathrm{Ln}^{3+}$ upon contact with MWCNT at pH 6.

\subsection{Summary and Recommendations}

Research and development activities completed under this project have established that a number of inorganic and hybrid ion-exchange materials exhibit varying affinities for actinides and lanthanides, which may be exploited for effective separations. The following concepts have emerged as the leading, but not exclusive, candidates for effective ion-exchange separations, (1) oxidation of $A m(I I I)$ to $A m(V)$ followed by ion exchange, (2) ion exchange of $A m(I I I)$ and fission products (Lanthanides, Cs, Sr, Tc) followed by recovery of the Am using an oxidizing eluent, (3) ion exchange of actinyls followed by the recovery of the Am as Am(III) using a reducing eluent, and (4) chromatographic separation. It is recommended that studies be continued to advance the ion-exchange technology for separating minor actinide and lanthanides.

\section{REFERENCES}

1. Minor Actinide Separations Using Ion Exchangers. D.T. Hobbs, T. C. Shehee, A. Clearfield, Technical Report, FCRD-SWF-2012-000242 (SRNL-STI-2012-00537), Savannah River National Laboratory, Aiken, SC, September 13, 2011.

2. Synthesis, crystal structures, and ion-exchange properties of a novel porous titanosilicates. D.M. Poojary, R.A. Cahill, A. Clearfield, Chem. Mater. 1994, 6, 2364.

3. Syntheses, crystal structures, and ion-exchange properties of porous titanosilicates, $\mathrm{HM}_{3} \mathrm{Ti}_{4} \mathrm{O}_{4}\left(\mathrm{SiO}_{4}\right)_{3} \cdot 4 \mathrm{H}_{2} \mathrm{O}\left(\mathrm{M}=\mathrm{H}^{+}, \mathrm{K}^{+}, \mathrm{Cs}^{+}\right)$, structural analogues of the mineral pharmacosiderite. E.A. Behrens, D.M. Poojary, A. Clearfield, Chem. Mater. 1996, 8, 1236.

4. Titanium silicates, $\mathrm{M}_{3} \mathrm{HTi}_{4} \mathrm{O}_{4}\left(\mathrm{SiO}_{4}\right)_{3} \cdot 4 \mathrm{H}_{2} \mathrm{O}\left(\mathrm{M}=\mathrm{Na}^{+}, \mathrm{K}^{+}\right)$, with three-dimensional tunnel structures for the selective removal of strontium and cesium from wastewater solutions. E.A. Behrens, A. Clearfield, Microporous Materials 1997, 11, 65.

\section{We put science to work."'}


5. Optimizing Cs-exchange in titanosilicate with the mineral pharmacosiderite topology: framework substitution of $\mathrm{Nb}$ and Ge. A. Tripathi, D. G. Medvedev, J. Delgado, A. Clearfield, Journal of Solid State Chemistry 2004, 177, 2903-2915.

6. Syntheses, X-ray Powder Structures, and Preliminary Ion-Exchange Properties of Germanium-Substituted Titanosilicate Pharmacosiderites: $\mathrm{HM}_{3}(\mathrm{AO})_{4}\left(\mathrm{BO}_{4}\right)_{3} \cdot 4 \mathrm{H}_{2} \mathrm{O}(\mathrm{M}=$ $\mathrm{K}, \mathrm{Rb}, \mathrm{Cs} ; \mathrm{A}=\mathrm{Ti}, \mathrm{Ge} ; \mathrm{B}=\mathrm{Si}, \mathrm{Ge})$. E.A. Behrens, D.M. Poojary, A. Clearfield, Chem. Mater. 1998, 10, 959-967.

7. Adsorption of lead on multi-walled carbon nanotubes with different outer diameters and oxygen contents: Kinetics, isotherms and thermodynamics. F. Yu, Y. Wu, J. Ma, C. Zhang, Journal of Environmental Sciences 2013, 25(1) 195-203.

8. Mesoporous Carbon Materials: Synthesis and Modification. C. Liang, Z. Li, and S. Dai. Angew. Chem. Int. Ed. 2008, 47, 3696 - 3717.

9. Competitive adsorption of $\mathrm{Pb}^{2+}, \mathrm{Cu}^{2+}$ and $\mathrm{Cd}^{2+}$ ions from aqueous solutions by multiwalled carbon nanotubes. Y.-H. Lia, J. Dinga, Z. Luanb, Z. Dia, Y. Zhua, C. Xua, D. Wu , B. Wei, Carbon, 2003, 41, 2787-2792.

10. Sorption behavior of $\mathrm{Cu}(\mathrm{II}), \mathrm{Pb}(\mathrm{II})$, and $\mathrm{Zn}(\mathrm{II})$ onto carbon nanotubes. K. Pyrzynska; A. Stafiej, A. Solvent Extraction and Ion Exchange, 2012, 30 (1), $37-41$.

\section{INDICATORS OF PROJECT QUALITY AND PRODUCTIVITY}

\section{Journal Publications}

1. "Separation of americium and lanthanides using titanium-based materials", Elvington, M.C.; Shehee, T.C.; Rudisill T.S. and Hobbs, D. T.; Solvent Extraction and Ion Exchange, 2012, 30(7), 669-682.

2. "Separation of oxidized americium from lanthanides by use of pillared metal(IV) phosphate-phosphonate hybrid materials.” Burns, J. D.; Borkowski, M.; Clearfield, A.; and Reed, D. T. Radiochim Acta, 2012, 100, 381 - 387.

\section{Presentations}

1. "Ion Exchange Based Separations of Minor Actinides", T. C. Shehee, A. A. Alsobrook, R. Silbernagel, A. Clearfield and D. T. Hobbs, presented at the $37^{\text {th }}$ Actinide Separations Conference, Spokane, WA, June 24 - 27, 2013.

2. "Minor Actinide Separations using Ion Exchangers", T. C. Shehee and D. T. Hobbs, presented at the 37 $7^{\text {th }}$ Actinide Separations Conference, Spokane, WA, June 24 - 27, 2013.

3. "Ion Exchange Performance of Titanosilicates and Carbon Nanotubes”, A. N. Alsobrook and D. T. Hobbs, presented at the $37^{\text {th }}$ Actinide Separations Conference, Spokane, WA, June $24-27,2013$.

4. "Unconventional Metal-Organic Frameworks (UMOFs) for Separation of Lanthanides from Actinides and Americium from Curium”, R. Silbernagel, J. D. Burns, A. Clearfield, T. C. Shehee and D. T. Hobbs, presented at the $37^{\text {th }}$ Actinide Separations Conference, Spokane, WA, June 24 - 27, 2013.

\section{COLLABORATORS AND PARTICIPANTS}

Participants in the ion-exchange research include Dr. David Hobbs (SRNL), Dr. Thomas Shehee (SRNL), Dr. Andrea Alsobrook, (postdoctoral researcher, SRNL), Prof. Abraham Clearfield,

\section{We put science to work. ${ }^{\text {'m }}$}


(TAMU), Jonathan Burns and Rita Silbernagel (graduate students, TAMU). Dr. Don Reed and Dr. Marian Borkowski of Los Alamos National Laboratory in Carlsbad, NM are unfunded collaborators who provided laboratory facilities, actinide materials, and technical assistance to J. Burns (TAMU) for the measurement of ion-exchange performance of the hybrid ion exchangers with radioactive materials.

We put science to work."' 